\title{
Determinants of Peri-Urbanization and Land Use Change Patterns in Peri-Urban Ghana
}

\author{
Divine O. Appiah ${ }^{1}$, John T. Bugri ${ }^{2}$, Eric K. Forkuo ${ }^{3} \&$ Peter K. Boateng ${ }^{4}$ \\ ${ }^{1}$ Department of Geography and Rural Development, Kwame Nkrumah University of Science and Technology, \\ (KNUST) Kumasi, Ghana \\ ${ }^{2}$ Department of Land Economy, Kwame Nkrumah University of Science and Technology, (KNUST) Kumasi, \\ Ghana \\ ${ }^{3}$ Department of Geomatic Engineering, Kwame Nkrumah University of Science and Technology, (KNUST) \\ Kumasi, Ghana \\ ${ }^{4}$ School of Geography and Environmental Science, Monash University, Australia
}

Correspondence: Divine Odame Appiah; Department of Geography and Rural Development, Kwame Nkrumah University of Science and Technology, (KNUST) Kumasi, Ghana. Tel: 233-2-6797-9012. E-mail: dodameappiah@yahoo.com

\author{
Received: September 14, 2014 Accepted: October 7, 2014 Online Published: November 23, 2014 \\ doi:10.5539/jsd.v7n6p95 \\ URL: http://dx.doi.org/10.5539/jsd.v7n6p95
}

\begin{abstract}
The main aim of this paper is to examine the effects of peri-urbanization on peri-urban land use change patterns, using a binary logistic regression model, in the Bosomtwe district of the Asante region, Ghana. The decision to convert from agricultural land uses to residential and commercial land uses are driven by a myriad of factors, ranging from social to economic in the Bosomtwe District. A triangulation of qualitative and quantitative design was used. Household questionnaires were proportionately administered to 270 respondents in 14 communities, on the basis of population. The data was subjected to the Pearson's Chi-square, Nigelkerk $R^{2}$ and Cramer's $V$ test of strength of association. Astep-wise binary logistic regression modeling was performed using the PASW v.17. Pearson chi-square value of $\chi^{2}=73.546$ at 26 degrees was significant at $p<.000$,athough the Cramer's V test of the strength of the association was moderate at $V=0.37$. The logistic regression model reported an overall significance of the model at $p<.000$ with $\chi^{2}=24.453$, at 4 degrees of freedom. The confidence intervals of (CIs) of (CI: 1.358 - 4.517) and (CI: 1.039-11.486) for the two main predictors of the outcome, and a B(Exp) values ranging between 2.477 and 3.455 were also reported. This means the odds of respondents being more likely to change their land uses is about $66 \%$. Increasing rate of peri-urbanization is caused by increasing demand for residential, recreational (Hotels and Guest houses) and commercial land uses at the expense of agro-forest land uses. These have some negative implications on local climate and food security. The District assembly should strictly monitor physical development in line with planning schemes.
\end{abstract}

Keywords: peri-urban, land use conversion and transformation, agro-forest land use, Bosomtwe district, Ghana

\section{Introduction}

\subsection{Problem and Background}

In Ghana, the outward expansion of cities into peri-urban areas consequently changes the land use patterns in these areas (Owusu, 2008). These, to a large extent, have had dire consequences on peri-urban land use decisions (Duta, 2008; Kombe, 2005). The peri-urban areas have and continue to experience incessant push and pull tendencies from the cities and the rural areas due to their strategic locations, and multifunctional territorial nature (Ravetz, Fertner, \& Nielsen, 2013). These areas also come about when urban residents buy up prime agricultural land outside the main cities for residential or commercial purposes (Samat, Hasni, Elhadary, \&Abdalla, 2011; Mandere, Ness \& Anderberg, 2010). According to Lawanson, Yadua, and Salako (2012) in their study of Lagos and Ibadan in Nigeria, the preference for the peri-urban areas for settlement and other commercial pursuits, is motivated by the fact that these fringes of cities have some of the relatively affordable rent in comparison to the main city and big towns (see also Acheampong \& Anokye, 2013). 
Again, according to Simon (2008), peri-urban areas are increasingly attracting middle-class and higher-income people whose lives exhibit lifestyles reflective of inner-city dwellers in a predominantly rural setting. Allen, Dávila, and Hofmann (2006; 21), have explained that the peri-urban interface comprises a 'heterogenous mosaic' of environmental and productive ecosystems working in combination with the prevailing socio-economic peculiarities. This supports the view that peri-urban lands are used for multiple activities. Similarly, peri-urban areas may contain a (dis)organized cluster of residential, commercial, rural-residential, and often varied agricultural uses (Mandere, Ness \& Anderberg, 2010). It is along this reasoning that one can observe that from a progressively agrarian to a rapidly urbanizing district, the Bosomtwe district of the Ashanti region of Ghana exhibits appreciable traits of peri-urbanism, with its concomitant land use and land cover change decisions.

Quite appreciably, many reports have revealed that changing economic conditions and technological advancements have been mediated by institutional factors and have contributed to the various significant intractable changes in land use and land cover (LULC) in peri-urban fringes (Lambin et al., 2001; Lawanson et al., 2012; Pitman et al., 2009; Brovkin et al., 2009). Land owners and land managers, operating within certain constraints, make decisions regarding transformations in land uses, based on factors that are largely political and socio-economic; however in most cases economic rationality has been the main driver (Irwin and Geogeghan, 2001). These are invariably defined within a range of directly related variables such as subsidies; rent prices, land values and the associated benefits of space in preferred areas (Amoateng, Cobbinah \& Owusu-Adade, 2013).

According to Masanja, (1999), there are two major driving forces for conversion and transformation of land use in the peri-urban peripheries; these are demands for housing for the growing population (Acheampong \& Anokye 2013) and the deteriorating housing conditions and inadequate urban services (Doos, 2012). Further, another reason for the conversion of land was advanced by Webster, (2002), as being a result of higher economic gains from conversion and transformation to other land uses other than agriculture. With economic rationality of the land owners, they would opt for other activities with higher future earning returns on their land, against agriculture (Irwin \& Geogeghan, 2001), in the end, subtly creating pressures on food security in the areas.

Access to and use of land and its cover is structured and usually constrained by policies and other institutional prohibitions both at the local (household) and national level (Lambin et al., 2003). At the household level especially under customary land holdings, with usufruct tendencies (Arko-adjei, 2011), it is difficult for the custodian of the land to allocate the land to any other uses without the express consent of the family and clan, for whom the land is held in trust (Bugri, 2008).Stretching the argument to the national and institutional spectrum, district assemblies, for instance owe it a duty to ensure that land resources within their domains of jurisdiction are spatially planned according to laid down plans (Appiah, Osman, \& Boafo, 2014; Kasanga \& Kotey, 2001). In both instances, there is the need to consider the collective interests of a wider population in taking any decisions of land use and modification.

However, the situation of land use conversion and transformation tends to be different when the power of decision making lies with the households (Deadman, $n d$.). Under these conditions, pertinent non-market/noneconomic factors including, environmental conditions and societal decision making systems are not often considered (Owusu, 2008). In furtherance of this view, Sunderlin et al., (2001), on resource management and other social network interests and rational economic decisions that would inure to the short to medium term benefit of the households are taken by the household decision agents. These decisions, are in most cases deemed utilitarian; in the collective interest of the household in response to social and economic changes/stresses that affects the livelihoods of the household (Afriyie, Abass \& Adomako, 2013).

It has been argued that the perspectives of free enterprises promotion and the encouragement of private sector development are the engines of growth for developing economies (Organization for Economic Co-Operation and Development, 2006). The argument has been stretched to favour the so-called private sector promotions in the areas of real estate development, hotels, hospitality and recreation as well as commercial establishments for job creation and to stimulate economic growth according to the Ghanaian government's Growth and Poverty Reduction Strategy (GPRS II 2006 - 2009) (National Development Planning Commission, NDPC hereafter, 2005). But problematically, there has been the temptation to gloss over the implications of these 'rational economic impetuses' on land and other environmental resources.

By this subtle invitation for private sector development, large-scale land acquisition has dispossessed a substantial proportion of smallholder farmers, as smallholders who did not have formal leases to their land and have been priced out of the land markets (Afriyie, et al., 2013). This quest has in recent years transformed itself cunningly, into what is happening in the global south as land grabbing for other commercial undertakings. Large 
tracts of land are being acquired for the cultivation of crops other than food crops (ActionAid, 2012). This situation paints a rather gloomy food security picture in the near future for local subsistent households (Vlolijk, 2013).

Measured against the levels of competition for land that are characteristic of peri-urban areas (Samat et al., 2011), it stands to reason that many peri-urban areas are formed from the innate tendencies of 'panic acquisition' and speculative plundering of land resources. The Bosomtwe district holds potential for this tendency; as some migrants and settlers in the district are seemingly taking advantage of the relatively lower grounds rent per pieces of plot of land in the area. The manifestation of these speculative acquisitions have been land-use/cover conversions and transformations away from agro-forestry ones, with increased potentials for food insecurity and degradation of other environmental resources in the district.

The consequences of agricultural and forest land degradation has been the increasing emission of greenhouse gases (GHGs) with warming effects on local climate. This would affect subsistent rain-fed agriculture, which dominates the local occupations mix. The effects of land-use/cover conversions and transformations away from agro-forestry, when persistent, results in food insecurity. Further, a perpetuation of poverty in a difficult to break cycle would also ensue. The foregone arguments are advanced considering the potentials of land use conversions and transformation tendencies in the context of the Bosomtwe district in the Ashanti region. As a way of stimulating the debate on regulated planning and schematic spatial organization of peri-urban land uses in the country, the focus of this paper is to examine the determining factors of peri-urbanization on the peri-urban land uses, in terms of the conversions and transformations, using a binary logistic regressing model. The Bosomtwe district of the Asante region of Ghana is used as a case study.

\section{Methodology}

\subsection{Profile of the Study Area}

The Bosomtwe District is located in the central part of the Ashanti Region. . It lies within Latitude $6^{\circ}$ $28^{\prime} \mathrm{N}$-Latitude $6^{\circ} 40^{\prime} \mathrm{N}$ and Longitudes $1^{\circ} 20^{\prime} \mathrm{W}$-Longitude $1^{\circ} 37^{\prime} \mathrm{W}$. Kuntenase is the District Capital. It spreads over a land area of $718 \mathrm{~km}^{2}$ (Figure 1). The District is bounded to the North by Atwima Nwabiagya and Kumasi Metropolis and to the East by Ejisu-Juaben Municipal. The southern section is bounded by Amansie West and East Districts, all in the Ashanti Region of Ghana.

Lake Bosomtwe, the largest natural (crater) lake in Ghana is located in the district. With the exception of the Lake which has an outer ridge that maintains a constant distance of $10 \mathrm{~km}$ from the center of the lake and stands at an elevation of 50 to $80 \mathrm{~m}$, the rest of the district has other varying unique topographical features. The drainage pattern of rivers and streams draining the Bosomtwe District is dendritic and centripetal in outlook. Around Lake Bosomtwe, there is an internal drainage where the streams flow from surrounding highlands into the lake in a centripetal fashion. The streams form a dense network due to the double maxima rainfall regime. Notable rivers in the district are rivers Oda, Butu, Siso, Supan and Adanbanwe. 


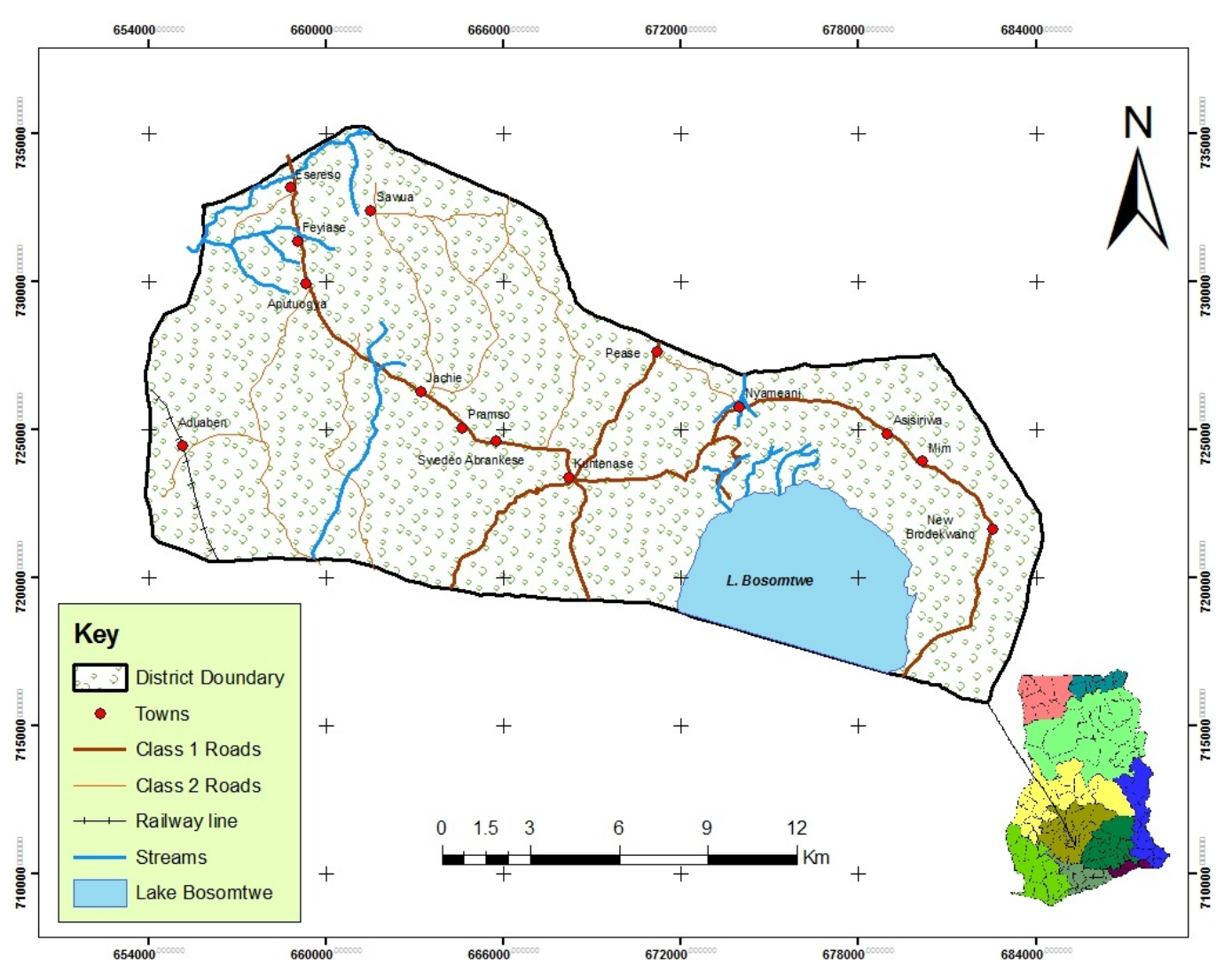

Figure 1. Map of the Bosomtwe District showing the study communities in Ghana

The district falls within the equatorial zone of climate with a rainfall regime typical of the moist semi-deciduous forest zone of the country. There are two well-defined rainfall seasons. The main season occurs from March to July, while the minor season occurs from August to October with mean annual rainfall of about 1,900 mm. The mean monthly temperature is about $36^{\circ} \mathrm{C}$ with a relative humidity of between 60 to $85 \%$.

The district falls within the Moist Semi-Deciduous Forest zone where different species of tropical hard woods with high economic value can be found. The tree species found in the district include; Wawa (Triplochiton scleroxylon), Mahogany (Khaya ivorensis), and Onyina (Ceiba pentandra) among others. In certain parts of the district, however, the original forest cover has been turned into secondary forest and grassland through indiscriminate exploitation of timber and inappropriate farming practices such as the slash and burn system and illegal gold mining activities.

The physical growth of settlements in the district is influenced by distance between the settlement and the Kumasi Metropolis. Further, the presence of infrastructure, socio-economic activities, the tourism sector improvements are all value additions to various land uses and cover. These make the district one of the potentially boisterous in the Ashanti Region.

\subsection{Sampling Design, Instruments and Data Analysis}

The study analyzed land use conversion potentials and their resulting effects on forest cover changes, based on the land use decision of the respondents; i.e. male and female-headed households. These were proportionately sampled from 14 communities in the Bosomtwe district of the Ashanti region of Ghana. The respondents were to demonstrate their perceived rate of forest cover depletions given the conditions that influence their land use decisions in the district. A sample size (n) of 270 household respondents was determined by the $n=(Z \alpha)^{2} x$ $[P(1-P)] / \mathrm{d}^{2}$, where $Z \alpha=5 \%$ level of significance, $P=$ expected proportion and $d=$ margin of error (Daniel, 1999), cited in Naing, Winn and Rusli (2006). The sample population was disaggregated by gender and systematically sampled. Using a structured partially pre-coded questionnaire, we administered proportionately to the communities based on their respective population sizes according the 2011 District Assembly Scalogram.

The quantitative data gathered were subjected to Logistic regression analysis, the Pearson's Chi-square, Cramer's V statistics and Nigelkerk's tests of association, strength and correlation coefficient of determination 
respectively, all embedded in the Statistical Package for Service Solution (SPSS) version 17 and results displayed in tables, charts and graphs. A non-parametric test (One-Sample Kolmogorov-Smirnov Z- Test), was carried out to establish whether there is a significant difference between the peri-urban land uses and vegetation cover depletion in the district. The diagrams generated in the SPSS were exported to excel for editing for better visual presentation. Open-ended qualitative responses were integrated in the discussions under the various thematic treatments of the sections of the paper.

\subsection{The Logistic Regression Model}

Using a log transformation of the probability p-values to a log distribution makes it possible to relate the binary regression model to the normal regression model. The log transformation of the probability $p$ is called the logit of $p$ or logit (p) (King and Zeng, 2001). This predicts the logs of the rate of success as against the rate of failure. The Logit(p) is the $\log$ (to base e) of the odds ratio or the likelihood ratio that the dependent variable DV is 1 . Mathematically, the logit (p) model is expressed as:

$$
\log i t(p)=\log \left[\frac{p}{1-p}\right]=\ln \left[\frac{p}{1-p}\right]
$$

Whereas $\mathrm{p}$ can only range from 0 to $1, \operatorname{logit}(\mathrm{p})$ scale ranges from negative infinity to positive infinity $(-\infty \leq$ $\operatorname{logit}(\mathrm{p}) \leq+\infty)$ and is symmetrical around the logit of .5 (which is zero). The model eqn. 1 , can be rewritten in the form of the normal linear regression model ( $\mathrm{y}=\mathrm{a}+\mathrm{b}_{1} \mathrm{X}_{1}+\mathrm{b}_{1} \mathrm{X}_{2} \ldots$ etc.), as shown in eqn. 2

$$
\log i t[p(x)]=\log \left[\frac{p(x)}{1-p(x)}\right]=\ln \left[a+\beta_{1} X_{1}+\beta_{2} X_{2}+\beta_{3} X_{3} \ldots\right]
$$

Instead of the least-squared deviations criterion for the best fit, in normal regression, the logistic regression uses a maximum likelihood approach that maximizes the probability of getting the observed results, given the fitted regression coefficients derived by the analytical software in this case, the Predictive Analytic Software (PASW v.17). A as a result, the goodness of fit and overall significance statistics used in logistic regression are different from the ones used in linear regression models. The probability $\mathrm{p}$ can be calculated by rearranging eqn. 2 , as;

$$
p=\left[\frac{e\left\{a+\beta_{1} X_{1}+\beta_{2} X_{2}+\beta_{3} X_{3}+\ldots\right\}}{1+e\left\{a+\beta_{1} X_{1}+\beta_{2} X_{2}+\beta_{3} X_{3}+\ldots\right\}}\right]
$$

Where,

$\mathrm{p}=$ the probability that a case is in a particular category for the response variable,

$\exp =$ the base of natural logarithms (approx. 2.72),

$\mathrm{a}=$ the constant of the equation in particularly explicit in step-wise models, and

$\beta=$ the coefficient of the predictor variables.

\section{Results and Discussions}

\subsection{Socio-demographic Characteristics of the Respondents}

A careful look at Table 1 displays the various socio-demographic characteristics of the respondents surveyed during the study. In order to understand the data that emanates from household respondents, it is imperative to also understand their demographic backgrounds (Kumekpor, 2002). This would enable the researcher to disaggregate the data along some of these variables, as well as be able to ascertain some of the reasons underpinning the response trends. 
Table 1. The demographic data of respondents

\begin{tabular}{|c|c|c|c|c|}
\hline Variables & & Mean & St. dev. & p-value \\
\hline Gender of respondents & $N(\%)$ & & & \\
\hline Male & $139(51.5)$ & 1.4852 & .5007 & .058 \\
\hline Female & $131(48.5)$ & & & \\
\hline Total & $270(100)$ & & & \\
\hline Age of respondents & Frequency & 3.1593 & 1.63165 & $.002 *$ \\
\hline $20-35 \mathrm{yrs}$ & $52(19.3)$ & & & \\
\hline $36-45 \mathrm{yrs}$ & $62(23.0)$ & & & \\
\hline $46-55 \mathrm{yrs}$ & $43(15.9)$ & & & \\
\hline $56-65 \mathrm{yrs}$ & $43(15.9)$ & & & \\
\hline $66-75 \mathrm{yrs}$ & $44(16.3)$ & & & \\
\hline $76+\mathrm{yrs}$ & $26(9.6)$ & & & \\
\hline Total & $270(100)$ & & & \\
\hline Marital status & Frequency & 1.7333 & 1.0397 & .405 \\
\hline Married & $167(61.9)$ & & & \\
\hline Single & $32(11.9)$ & & & \\
\hline Widow/Widower & $47(17.4)$ & & & \\
\hline Divorced & $24(8.9)$ & & & \\
\hline Total & $270(100)$ & & & \\
\hline Educational Level & Frequency & 2.6704 & 1.20665 & .720 \\
\hline No Formal Education & $69(25.6)$ & & & \\
\hline Primary & $26(9.6)$ & & & \\
\hline JHS/Middle Sch. & $122(45.2)$ & & & \\
\hline SHS/Tech/Voc & $31(11.5)$ & & & \\
\hline Tertiary/Post Sec & $22(8.1)$ & & & \\
\hline Total & 270 & & & \\
\hline Household size & Frequency & 1.6037 & 1.03578 & .876 \\
\hline 1-5 people & $172(63.7)$ & & & \\
\hline 6-10 people & $66(24.4)$ & & & \\
\hline $11-15$ people & $13(4.8)$ & & & \\
\hline 16-20 people & $5(1.9)$ & & & \\
\hline 20+ People & $14(5.2)$ & & & \\
\hline Total & $270(100)$ & & & \\
\hline Main occupation & Frequency & 3.6148 & 2.59535 & $.002 *$ \\
\hline Farming & $129(47.8)$ & & & \\
\hline Artisans & $11(4.1)$ & & & \\
\hline Public/Civil Servant & $28(10.4)$ & & & \\
\hline Trading/Food vending & $51(18.9)$ & & & \\
\hline Artisans & $51(18.9)$ & & & \\
\hline Total & $270(100)$ & & & \\
\hline
\end{tabular}

${ }^{*} p$-values are significant at $\alpha=.05$ 
The gender characteristics of the heads revealed that a proportion of $52 \%$ of them were males while $48 \%$ of them were females. The age category of respondents was identified as between 22-35 years as the lowest and 76 years or more as the highest age cohorts, at 10 years interval respectively. Most of the respondents however emanated from the 36-45 age cohort; the category that can best be described as the working and middle-aged group. Either of the respondents were married- $62 \%$, Single- $12 \%$, Widowed- $17 \%$ or divorced with nine percent respectively.

The highest level of educational attainments of the respondents was tertiary and post-secondary education. However, majority of the respondents in the communities were educated up to the Junior Secondary School or the Middle School level with $45 \%$ representing this number. The next majority with $26 \%$, were those without any formal education.

Most of the households $64 \%$ had household sizes of between 1-5 people, sharing common dwelling and make 'common provision for food or other essentials for living by the UNDY (United Nations Demographic Yearbook, 2004, p.7), while the next most important household sizes of between 6 and 10 people inclusive, were responded to by $24 \%$; these were found in both single and or multiple households with $58 \%$ and $41 \%$ respectively.

Without implying that farming is the occupation of the illiterate, a greater proportion of the respondents, however, had formal education only up to the JSS/middle school level. This therefore means that they generally could not have the requisite qualification to seek employment in white-collar jobs. This explains the predominance of the major occupation in the communities, being farming with $49 \%$. The next most important vocations were trading, including food vending and artisanal works at $19 \%$ each of the respondents. Only $10 \%$ were employees of the public and civil service as per the samples from the various communities. This can be generalized for the entire district. Some of these socio-demographic data are of relevance to the respondents' disposition and bearing on the peri-urban land use change patterns. These have been used to cross-tabulate the responses for analyses. This has been done to establish relationships between them and the variables on the main issues of peri-urban land use and land cover change dynamics in the district.

\subsection{Main Causes of Peri-urbanization in the Bosomtwe District}

The main causes of peri-urbanization in the Bosomtwe district were identified among the respondents from all the 14 communities as follows; those that are driven by population and infrastructure expansion; the availability of excess land for which reason people are moving towards the district in speculation for land, ostensibly for residential and recreational purposes; and the perceived availability of social amenities that attract people for settlement into the district. The respondents maintained these were the main drivers of peri-urbanization of the Bosomtwe District.

From Figure 2, majority of the respondent $(50 \%)$ indicated that the increasing physical infrastructure in the communities, which has occurred as a result of population influx from the main urban areas of Kumasi and Atonsu townships, are that main drivers. Others were of the view that easy access to land constitutes the main driver of a pull factor attracting potential residential developers into the district to acquire land for building and commercial purposes. This was delivered with a response rate of $31 \%$. Some respondents (19\%), also indicated that the rate of peri-urbanization is caused by the presence of social amenities such as schools, clinics and potable water, among others, as the attracting medium for people to settle in the district. 


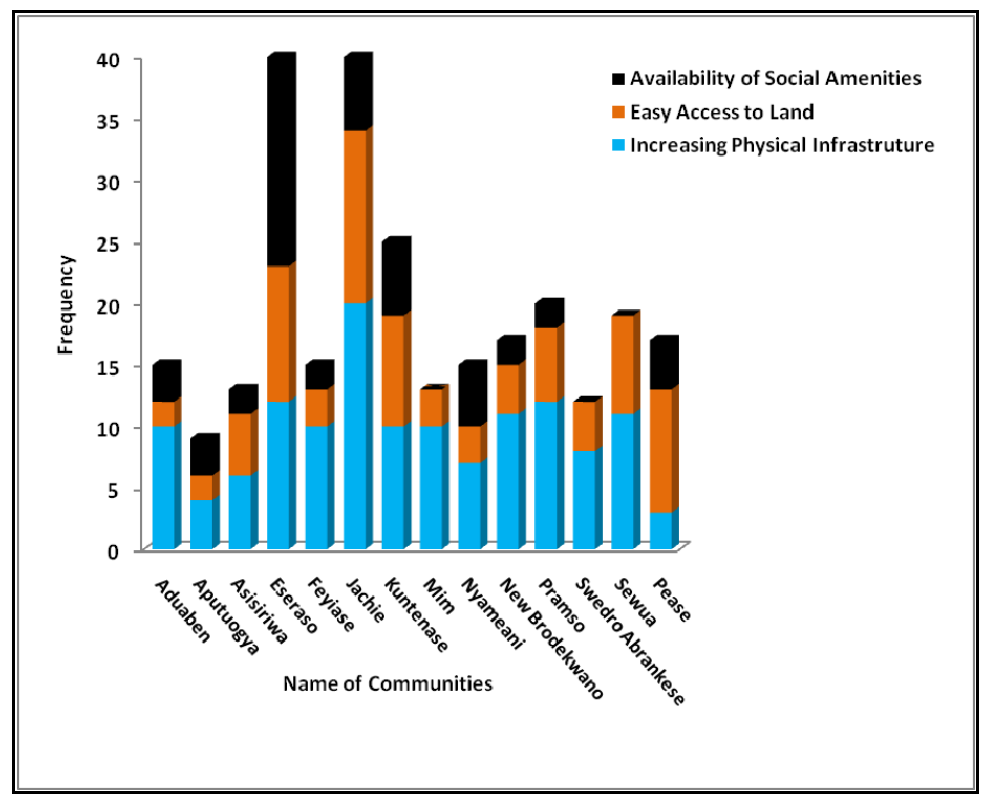

Figure 2. The main causes of peri-urbanisation according to respondents in the district

\subsection{Major Human Activities That Mostly Affect Land Uses as Per the Communities}

Results from the survey revealed that major human activities that have been affecting and determining land uses range from subsistence agriculture, residential to commercial and some recreational (predominantly the hospitality and resort) activities of land use. Communities such as Aduaben, Mim, Nyameani, Jachieand Feyaise with combined response rates ranging from $53 \%$ to $93 \%$, were predominantly agrarian. Therefore their responses pointed to the increasing subsistence agriculture to which land is put in these communities (Table 2).

Responses obtained from Aputuogya,Asisiriwa, Esreso, Pramso, Pease, Kuntenase and Swedro-Abrankese indicated that land uses for residential and commercial activities were the main human activities affecting land use conversions and transformation. The relative combined response rates ranged from $50 \%$ to $89 \%$. These responses for the two main human activities affecting land uses i.e. subsistent agriculture and residential with commercial activities were identified as highly preponderant in the specific communities indicated. Low to moderate land uses for the two activities also were identified by respondents in the other communities, with the exception of Aputougya where no respondent identified subsistent agriculture activities, with recreational land uses being on a very low side.

Table 2. Major human activities that mostly affect land uses/cover

\begin{tabular}{lcc}
\hline Land Uses (LUs) & Frequency & Valid Percent \\
\hline Increased Subsistence Agriculture LUs & 121 & 44.8 \\
Expansion in residential and commercial LUs & 140 & 51.9 \\
Recreation and Industrial (Small-scale) & 9 & 3.3 \\
\hline Total & $\mathbf{2 7 0}$ & $\mathbf{1 0 0}$ \\
\hline
\end{tabular}

A test of association was performed on the relationship between the community location and the type of human activities that have effects on land use dynamics. This was pre-informed by the reconnaissance survey which revealed the patterns of land uses per the communities visited during the survey. From the survey it was revealed that land in some of the communities was put to particular land use types, either due to their proximity to the main city and big towns, such as Atonsu, Kumasi and Esereso or others with relative location advantages. From the 2-tailed test of association, a Pearson chi-square value of $\chi^{2}=73.546$ at a degree of freedom, $d f=26$ and a significant value of $p<.000$. Although the Cramer's $\mathrm{V}$ test of the strength of the association was moderate at $V=$ 0.37 , it was significant. This implies that depending on the location of the community in relation other factors of 
land use demand, human land use types are location specific. This situation does not deviate from conventional principles of hedonic tendencies of land and their relative uses to which they are put.

\subsection{Relationship between Peri-urbanization and Peri-urban Land Use Change in the Bosomtwe District}

Respondents' understanding of the concept of peri- urbanization was juxtaposed against the main causes of peri-urban land use changes in the district. From Table 2, increasing availability of Physical Infrastructure, correlated well with the increasing infrastructure as a description for peri-urbanization with a combined percentage response of $47 \%$. Population increase in combination with the other causes such as availability and easy access to land and availability of social amenities yielded a combined response rate of $24 \%$. The response rate for those whose definition entailed the combination of the two processes in association as the main causes of peri-urbanization was $29 \%$.

The results from a 2-tailed analysis showed that there is no significant association between the two concepts, as a Pearson's chi-square value of 6.600 at a degree of freedom of 4 rather showed a p-value higher than $\alpha=.05$ $(p>.159)$ with a Cramer's V of .111. The result somewhat deviates from general expectations of peri-urban areas experiencing the kind of dynamics due to the aforementioned reasons. In a study by Cobbinah and Amoako, (2014), the physical manifestations of the peri-urban areas suggest the nature of transformations that have taken place over time. However, sufficient conditions have proven to be more potent in determining the association between what constitutes peri-urbanization and the associated causes of the process (Owusu \& Agyei, 2007), and as illustrated in Table 3.

Table 3. Main Drivers of peri-urbanization in the Bosomtwe District

\begin{tabular}{lcccc}
\hline \multicolumn{1}{c}{ Responses } & $\begin{array}{c}\text { Availability of Physical } \\
\text { Infrastructure }\end{array}$ & $\begin{array}{c}\text { Availability and Easy } \\
\text { access to Land }\end{array}$ & $\begin{array}{c}\text { Availability of } \\
\text { Social amenities }\end{array}$ & Total \\
\hline Increasing population & 31 & 22 & 12 & $\mathbf{6 5}$ \\
$\begin{array}{l}\text { Increasing infrastructure } \\
\text { Increasing population }\end{array}$ & 73 & 33 & 22 & $\mathbf{1 2 8}$ \\
and infrastructure & 30 & 29 & 18 & $\mathbf{7 7}$ \\
\hline \multicolumn{1}{c}{ Total } & $\mathbf{1 3 4}$ & $\mathbf{8 4}$ & $\mathbf{5 2}$ & $\mathbf{2 7 0}$ \\
\hline
\end{tabular}

The main uses of peri-urban lands in the district were identified as lands for residential, land for commercial and recreational activities and land for administrative purposes. These land uses were associated with the challenges identified as peculiar to peri-urban areas. These were human and vehicular traffic congestion, social vices and problems of multiple sales of same lands to multiple buyers, with its attendant social problems of land guards. (Land guards in the context of Ghanaian land tenure relations, refer to hired men usually thugs by any of the contending parties over a piece of land under dispute of multiple ownership). The results showed that there is no significant association between the two cases as a Pearson's chi-square value of 5.814 at a degree of freedom of 4 rather showed a p-value far higher than $\alpha=.05$ ( $\mathrm{p}>.213$ ) with a Cramer's V of .147.

\subsection{Land Use Activities Altering Peri-urban Land Use and Land Covers in the Bosomtwe District}

There was no doubt that there were certain human activities that have increased the rate of land-use/cover conversions and transformations in areas that are characterized as peri-urban. These have been espoused by Rodriguez, Beard, Bennett Jr., Cumming, Cork, Agard, Dobson, and Peterson, (2006) and Afriyie et al. (2014) and has also being identified in the Bosomtwe district (Figure 3). From the results, expansion in residential and commercial land uses were identified as the main human drivers of peri-urban land uses, constituting about $52 \%$ of the responses. The next in relevance was the increased subsistent agriculture with close to $45 \%$. In this case, the residents were largely applying rudimentary forms of land cultivation. These processes and methods include the slush and burn method of tillage with its consequences of tree cover and soil quality changes. Recreational and light industrial land use activities with only $3 \%$, was not seen as a popular land use activity in the district. Therefore the respondents did identify with this human land use activity that has the tendency to alter the land use and cover considerably. 


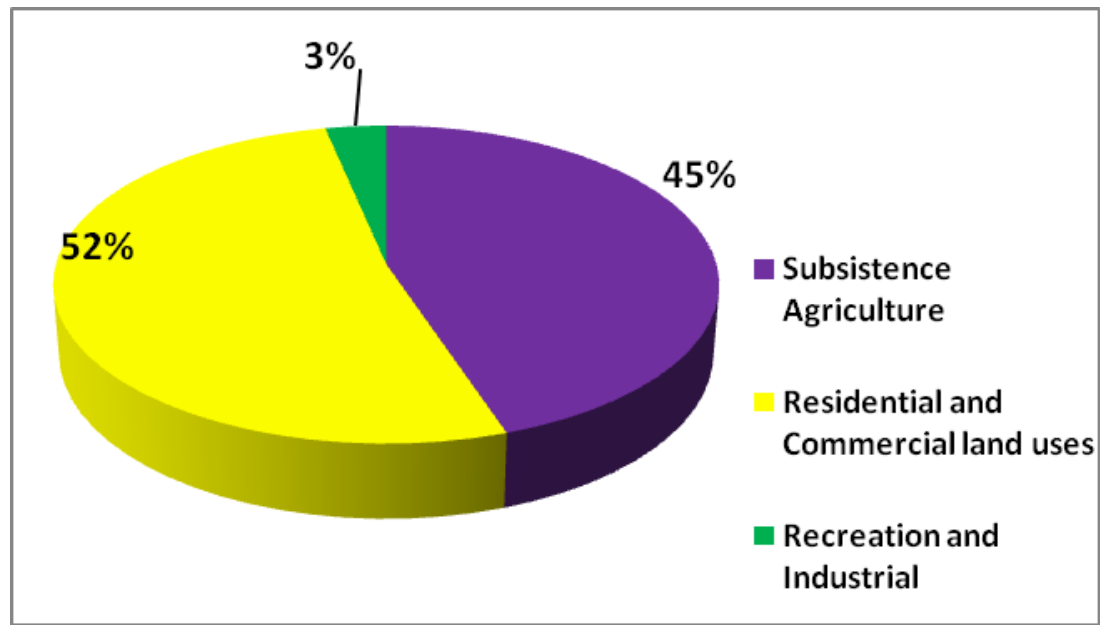

Figure 3. Main human activities that alter peri-urban land use and land covers

\subsection{Drivers of Competition for Peri-urban Land Use in the Bosomtwe District}

Also, of critical consideration were the main factors that determine land use and land cover change (LULCC) in peri-urban areas a priori. These are factors identified as de facto, to have followed as a matter of course, in areas where land use competition tends to be keener in response to various human economic motive-driven activities (Irwin \& Geogheghan, 2001). However the degree of intensities of these factors, depend largely on the social, economic, geographical and the ecological conditions of the area under consideration.

In the Bosomtwe district-a typical peri-urban area - these factors of land use competition drivers were identified as the ease of access to land by tenants as indicated by $29 \%$ of the respondents, changing demand trend in land uses identified by $34 \%$ of respondents. This factor may have other sub-drivers by other intrinsic factors. Majority of respondents (37\%) indicated that deteriorating livelihoods of land holders, owners and land lords, is the main driver which pushed them to yield their lands for certain land use activities for which economic incentives and motivation enticements were made (Figure 4).

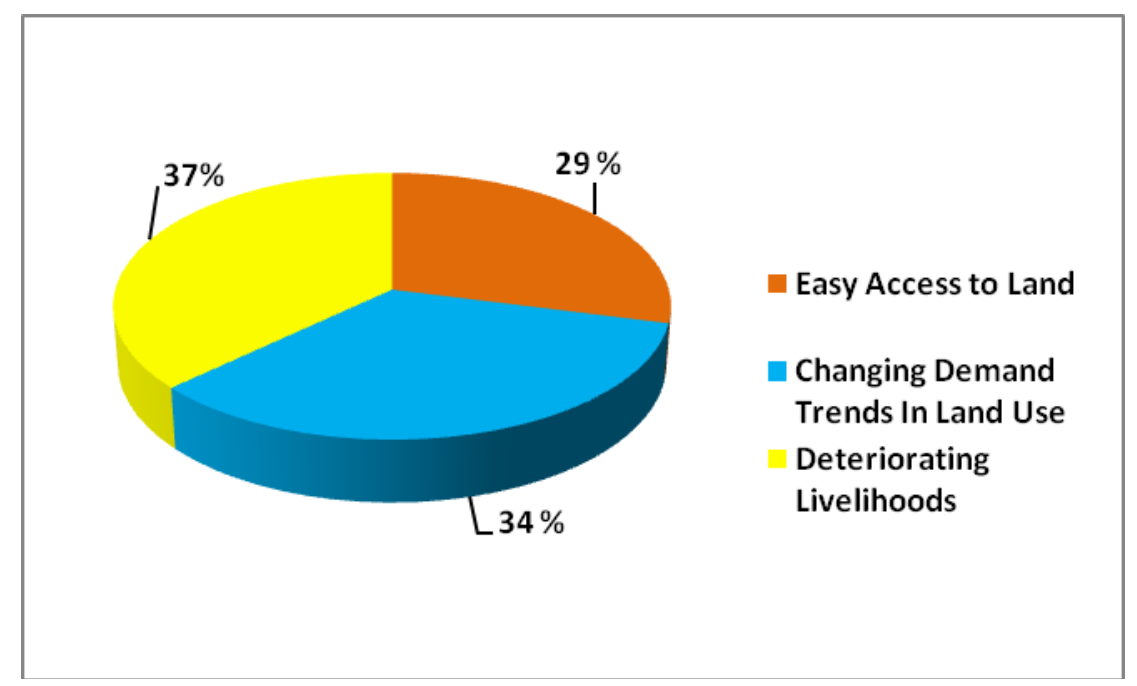

Figure 4. Main factors driving land use and land cover changes

\subsection{Fitting the Logistic Regression Model}

A logistic regression was also run to determine the effects the factors as the drivers as the independent variables (IV) or the predictors have to influence the dichotomous dependent variable (DV) or the response. The dichotomous responses to the dependent variables were that "whether the respondents would convert their arable land from present use to a different use? They were to respond as $1=$ "Yes, would convert" and $0=$ "No, would 
not convert". These were predicted by the conditional statements of the independent variables as, what if there are changes in: (1) the grounds rent per plot of land in the district;(2) the major human activities that affect land use and land cover in the district, (3) the income category of the people who predominantly settle in the peri-urban areas of the district and (4) the criteria used in determining the price/rent of a plot of land in the district, as the independent variable.

The analysis was conducted using a case-wise binary logistic regression in PASW, to ascertain the ODD likelihood of respondents taking a decisions to convert or not to convert their land to any other uses. These actions are taken in the form of the probability of the action occurring or not occurring as either 1 or 0 in binary logistic modeling (King \& Zeng, 2001).From the earlier analysis of the logistic regression model, we fit the outcome of the data in table 4 , the logistic regression table to determine the probability of conversions given the various independent variables. It is also to determine which of the predictor variables has the highest degree of influence in predicting the outcome of the land use conversion by the household agents. By fitting the logistic regression model to the variables, using the formula in eqn 3 , we calculated the respective odd ratios of the independent variables in predicting the outcome.

During the analysis, the null hypothesis stated that without the independent variables the model is a good fitting model. Alternatively, the other hypothesis was that the model is not a good fit without the inclusion of the independent variables in the model. At the case step 0, which is the beginning method the overall predicted percentage is $57.9 \%$; this is a measure of the fitness of the model when $y=$ the constant. The overall significance of the model without the independent variables was $\mathrm{p}<.000$. However with the inclusion of the independent variables (grounds rent per plot of land, major human activities, income category of settlers and criteria for determining rent of a plot of land), the overall significance of the model was also $p<.000$ at a chi-square value of 24.453 , at a 4 degree of freedom.

The overall percentage predictive accuracy of the step 1 model is $77.6 \%$ as against the $57.9 \%$ of the null (constant only) model. Three out of the four independent variables were of much significance in predicting the outcomes of household respondents. These were the grounds rent per plot of land in the district, the major human activities that affect land use and land cover in the district and the criteria used in determining the price/rent of a plot of land with probabilities of $p<.003, p<.011$ and $p<.043$ respectively, which is less than the significant level of .05. The model however was able to explain this prediction at only $37 \%$, at the Nagelkerke $\mathrm{R}^{2}=0.37$. There may, therefore, be other inherent explanations beyond the scope of the model to explain. Possible reasons could be the fact that the independent variables predicting the response variables, are not measured as categorically as the dependent variable in a ratio and/or interval scales to yield the exact numeric predicted outcomes, for which the model can succinctly explain.

The confidence intervals of (CIs) of (CI: $1.358-4.517)$ and (CI: 1.039-11.486) for the two main predictors of the outcome, and a $\mathrm{B}(\mathrm{EXP})>1$, ranging between 2.477 and 3.455 means that the odds of respondents being more likely to convert their land from original uses to other uses given the appropriate grounds rent on the land market, is higher. The probability of conversion is about 3 times when any of the two main predictor variables increase by one unit. Also, they would convert their land on condition that demand for their land meets the criteria of prospective tenants and buyers who are looking out for some criteria upon which the grounds rent is based.

Table 4. Variables in the step-wise binary logistic regression equation

\begin{tabular}{|c|c|c|c|c|c|c|c|c|}
\hline & & & & & & \multicolumn{3}{|c|}{$95 \% C I$} \\
\hline & $B$ & S.E. & Wald & $d f$ & Sig*. & $\operatorname{Exp}(B)$ & Lower & Upper \\
\hline The grounds rent/plot $\left(\mathrm{R}_{\mathrm{G}}\right)$ & .907 & .307 & 8.753 & 1 & .003 & 2.477 & 1.358 & 4.517 \\
\hline $\begin{array}{l}\text { Income category of settlers in peri- urban } \\
\operatorname{areas}\left(I_{\mathrm{PU}}\right)\end{array}$ & .479 & .396 & 1.458 & 1 & .227 & 1.614 & .742 & 3.509 \\
\hline $\begin{array}{l}\text { Major human activities on land uses/cover } \\
\text { changes }\left(\mathrm{A}_{\mathrm{H}}\right)\end{array}$ & -1.694 & .665 & 6.482 & 1 & .011 & .184 & .050 & .677 \\
\hline Criteria determining grounds rent $\left(C_{R}\right)$ & 1.240 & .613 & 4.091 & 1 & .043 & 3.455 & 1.039 & 11.486 \\
\hline Constant & -1.239 & 1.809 & .470 & 1 & .493 & .290 & & \\
\hline
\end{tabular}

*Test is significant at .05 


$$
p=\left[\frac{\left.e\left\{a+\left(0.907 R_{G}\right)+\left(1.240 C_{R}\right)+0.479 I_{P U}\right)-1.239\right\}}{\left.1+e\left\{a+\left(0.907 R_{G}\right)+\left(1.240 C_{R}\right)+0.479 I_{P U}\right)-1.239\right\}}\right]
$$

The odds for the likelihood of a change in any of the independent variables in predicting the dependent category can thus be determined from the odds ratio or the logit of probability $(p)$ function above and determined by the (EXP) $\beta$ in table 4.With references to the odds ratio, the likelihood of a change in any of the independent variables in predicting the dependent category can thus be determined from the number times respondents expect the peri-urban land, particularly agricultural land to change (reduce) by degree of certainty of occurrence. The ground rent per plot of land and the criteria used in determining it and to a large extent the income category of peri-urban dwellers have significant determining influences on the conversion of land into others, such as, residential, hospitality (Hotels and Guest houses) and commercial land uses, as shown in Eqn. 4. The probability (p), above indicates about more than 3 times higher odds of occurrences, as would be anticipated by the respondents in the district.

\subsection{Relevance and Implications}

The Bosomtwe district in the Ashanti region, like any other peri-urban area, is experiencing a number of determining factors that are contributing to land use and land cover changes. These are in the form of either land use conversions and/or land use modifications (Lambin, Baulies, Bockstael, Fischer et al., 2000). There were a number of factors that determined the preponderance of the different responses to the changing patterns of land use and land cover (LULC). Sometimes, some of the factors were just extremely significant in determining the land use chance patterns in the study area. As the core urban areas such as Atonsu, Esereso and Kumasi are becoming seemingly congested, the spill-over effect of urban population's relocation is affecting the Bosomtwe district to also grow in response to the pulling-up effect scenario, reported by Acheampong and Anokye, (2013).

Although the Bosomtwe district is predominantly rural, its peri-urbanization process is gaining momentum; a situation which gears toward a fully-fledged urbanized district in the future. Accordingly, motivated by the affordability of land in the peri-urban areas, Lawanson, Yadua, and Salako (2012) concluded many people would want to resettle from the big cities to the rural to peri-urban fringes. One of the manifestations of peri-urban land-use changes is the dynamic physical and environmental modifications (Cobbinah and Amoako, 2014). This scenario was the driver behind people in the district, to engage in speculative demand for land in the district for the purpose of residential, hospitality (hotels/guest houses) and commercial land uses, it is obvious that potential settlers are taking advantage of the fast growing surrounding bigger towns to 'secure their place' in the district in anticipation for the future urban status of the district. Consequently, results of Ravetz et al., (2013), Dutta, (2012) and Kombe, (2005) seem to be corroborated by findings of this study that, there is evidence why some of the respondents indicated their motivation to acquire land in the district being the potential optimism of a future economic boom in the district.

It is of no surprise that among the various reasons given for causes of peri-urbanization in the district, the respondents indicated that increasing physical infrastructure and easy access due to relatively cheaper rent on land are their motivations (Cobbinah \& Amoako, 2014; Lawanson, et al., 2012). They also indicated that with some level of availability of social amenities there is the tendency for population movements toward the district for settlement. These, in combination, drive the peri-urbanization processes and land use change dynamics in the Bosomtwe district.

\section{Conclusions and Recommendations}

As agriculture and forest land uses (AFOLU) are gradually losing their prominence with time, demand for other land uses are soaring considerably. In the event that households would have to make decisions as to what use to put their land to, given the reasons of, for instance, deterioration of livelihoods from subsistent agriculture, and the social complacency of professing excess land available and the changing demand for land uses, the decision-maker household heads would not hesitate to convert their land to other land uses.

In most cases, the probability (odds) of converting from one land use to another will be high, as has been explicitly reported by the logistic regressing model. According to the respondents, many landowners would change the use of their lands with some high certainty if factors that determine their land use preferences change. Their claim was that unprofitability of agriculture and alternatively high prices offered for land meant for other uses (residential, recreational and commercial) in recent times, compelled the majority of farmers to decide to convert their arable lands from agriculture to other uses.

Throughout the study however, the role of the Bosomtwe district assembly through its agent of the Town and 
Country Planning Department (TCPD) has been silent. The Assembly through its allies of the Office of the Stool Lands (OSL) needs to regulate and oversee the management of land tenure arrangements such that agro-forestry land-uses/covers do not lose out in the long-term, with its concomitant effects on food security and environmental management. It is thus imperative to ensure adherence to the laid-down physical planning regulations and schemes which regulate the boundaries of land uses and land covers through zoning. The Assembly should also take steps towards improving the security of land tenure, be it customary or statutory, to forestall land disputes and the emerging social problems of land guards.

\section{Acknowledgement}

The authors wish to acknowledge Department of Geography and Rural Development and the School of Geography and Environmental Science of the Kwame Nkrumah University of Science and Technology and Monash University respectively, for the provision of the office space and logistical support for this study. We also thank WASCAL for funding. We are also grateful to the positive contributions of Miss. Stella A. Adiaba of Keel University, United Kingdom, for her careful proof-reading of this manuscript. Finally, we acknowledge with thanks, the secondary sources of materials reviewed and cited.

\section{References}

Acheampong, R. A., \& Anokye, P. A. (2013). Understanding Households' Residential Location Choice in Kumasi's Peri-Urban Settlements and the Implications for Sustainable Urban Growth. Research on Humanities and Social Sciences, 3(9), 60-70.

Action Aid. (2012). Land grabbing, biofuel investment and traditional authorities in Ghana; Executive Summary, Policy Brief. Retrieved August 15, 2014, from http://www.actionaid.org/sites/files/actionaid/policy_brief.pdf

Afriyie, K., Abass K., \& Adomako, J. A. A. (2013). Urbanization of the Rural Landscape: Assessing the Effects in Peri-urban Kumasi. International Journal of Urban Sustainable Development, 6, 1-19. Retrieved March 28, 2013 from http://www.tandfonline.com/doi/abs/10.1080/19463138.2013.799068\#preview

Allen, A., Dávila, J. D., \& Hofmann, P. (2006). The Peri-urban Water Poor: Citizens or Consumers? Environment and Urbanization, 18(2), 333-351. http://dx.doi.org/10.1177/0956247806069608

Amoateng, P., Cobbinah, P. B., \& Owusu-Adade, K. (2013). Managing physical development in peri-urban areas of Kumasi, Ghana: A case of Abuakwa. Journal of Urban and Environmental, 7(4), 96-109. http://dx.doi.org/10.4090/juee.2013.v7n1.096109

Appiah, D. O., Osman, B., \& Boafo, J. (2014). Land Use and Misuse; Human Appropriation of Land Ecosystems Services in Ghana. International Journal of Ecosystem, 4(1), 24-33.

Arko-Adjei, A. (2011). Adapting land administration to the institutional framework of customary tenure; the case of peri-urban Ghana. Sustainable Urban Areas, 39, 284. The Netherlands.

Bugri, J. T. (2008). The Dynamics of Tenure Security, Agricultural Production and Environmental Degradation in Africa: evidence from stakeholders in north-east Ghana. Land Use Policy, 25, 271-285. http://dx.doi.org/10.1016/j.landusepol.2007.08.002

Cobbinah, P. B., \& Amoako, C. (2012). Urban Sprawl and the Loss of Peri-Urban Land in Kumasi, Ghana. International Journal of Social and Human Sciences, 6, 388-397.

Daniel, W. W. (1999). Biostatistics: A foundation for Analysis in the Health Sciences (7th ed.). New York: John Wiley \& Sons.

Deadman, P. (n. d.). Household decision making and patterns of land use change in LUCITA: An agent based simulation of the Altamira region, Brazil. Retrieved May 8, 2014, from http://www.mssanz.org.au/modsim05/papers/deadman.pdf

Dutta, V. (2012). Land Use Dynamics and Peri-urban Growth Characteristics Reflections on Master Plan and Urban Suitability from a Sprawling North Indian City. Environment and Urbanization ASIA, 3(2), 277-301. http://dx.doi.org/10.1177/0975425312473226

Irwin, E. G., \& Geoghegan, J. (2001). Theory, Data, Methods: Developing Spatially Explicit Economic Models of Land Use change. Agriculture, Ecosystems and Environment, 85, 7-23. http://dx.doi.org/10.1016/S0167-8809(01)00200-6

Kasanga, K., \& Kotey, N. A. (2001). Land management in Ghana: building on tradition and modernity. International Institute of Environment and Development, London. Retrieved June 19, 2014, from 
http://www.pubs.iied.org/pdfs/9002IIED.pdf?pagewanted=all

King, G., \& Zeng, L. (2001). Logistic regression in rare events data. society for political methodology. Retrieved May 18, 2013, from http://gking.harvard.edu/files/0s.pdf

Kombe, W. J. (2005, March). Land use dynamics in peri-urban areas and their implications on the urban growth and form: The case of Dar es Salaam. Tanzania Habitat International, 29(1), 113-135. http://dx.doi.org/10.1016/S0197-3975(03)00076-6

Kumekpor, T. K. B. (2002). Research methods and techniques of social research on life press and services Accra, Ghana.

Lambin, E. F., Baulies, X., Bockstael, N. E., Fischer, G., Krug, T., Leemans, R., ... Vogel, C. (2000). Land-Use and Land-Cover Change (LUCC), Implementation Strategy. IGBP Report 48, IHDP Report 10Stockholm, Bonn, IGBP, IHDP.

Lambin, E. F., Geist, H. J., \& Lepers, E. (2003). Dynamics of Land-Use and Land Cover Change in Tropical Regions. Annual Review of Environmental Resources, 28, 205-241. http://dx.doi.org/10.1146/annurev.energy.28.050302.105459

Lambin, E. F. et al. (2001). The Causes of Land-Use and Land-Cover Change: Moving Beyond the Myths. Global Environmental Change, 11(4), 261-269. http://dx.doi.org/10.1016/S0959-3780(01)00007-3

Lawanson, T., Yadua, O., \& Salako, I. (2012). Environmental challenges of peri-urban settlements in the Lagos megacity. In M. Schrenk, V. V. Popovich, P. Zeile, \& Pietro Elisei (Eds.), Proceedings of Real Corp 2012: Re-Mixing The City - Towards sustainability and resilience? Retrieved August 5, 2014, from http://www.corp.at/archive/CORP2012_40.pdf

Mandere, M. N., Ness, B., \& Anderberg, S. (2010). Peri-urban development, livelihood change and household income: A case study of peri-urban Nyahururu, Kenya. Journal of Agricultural Extension and Rural Development, 2(5), 73-83.

Naing, L., Winn, T., \& Rusli, B. N. (2006). Practical Issues in Calculating the Sample Size for Prevalence Studies. Archives of Orofacial Sciences, 1, 9-149. Retrieved August 16, 2104, from http://www.kck.usm.my/ppsg/aos/Vol_1/09_14_Ayub.pdf

National development planning Commission (NDPC). (2005). Growth and Poverty Reduction Strategy (GPRS II) (2006-2009). Retrieved August $\quad 15, \quad 2014, \quad$ from http://planipolis.iiep.unesco.org/upload/Ghana/PRSP/Ghana\%20PRSP\%20June\%202006.pdf

OECD. (2006). Promoting Pro-Poor Growth Private Sector Development. Retrieved August 5, 2014, from http://www.oecd.org/development/povertyreduction/36427804.pdf

Owusu, G. (2008). Indigenes and Migrants' Access to Land in Peri-Urban Areas of Accra, Ghana. International Development Planning Review, 30(2), 177-198. http://dx.doi.org/10.3828/idpr.30.2.5

Owusu, G., \& Agyei, J. (2007). Changes in Land Access, Rights and Livelihoods in Peri-urban Ghana: The case of Accra, Kumasi and Tamale metropolis. Institute of Statistical, Social and Economic Research (ISSER), Accra.

Ravetz, J., Fertner, C., \& Nielsen, T. S. (2013). Remaking Cities Contradictions of the recent urban environment. In K. Nilsson, S. Pauliet, S. Bell, C. Aalbers, \& S. T. Nielsen (Eds.), Peri-urban futures: Scenarios and models for land use change in Europe (pp. 13-44). Routledge Publications, New York, USA and Canada.

Samat, N., Hasni, R., Elhadary, E., \& Abdalla, Y. (2011). Modelling Land Use Changes at the Peri-urban Areas Using Geographic Information Systems and Cellular Automata Model. Journal of Sustainable Development, 4(6), 72-84. http://dx.doi.org/10.5539/jsd.v4n6p72

Simon, D. (2008). Urban Environments: Issues on the Peri-Urban Fringes. The Annual Review of Environmental Resources, 33, 167-185. http://dx.doi.org/10.1146/annurev.environ.33.021407.093240

Sunderlin, W. D., Angelsen, A., Resosudarmo, D. P., Dermawan, A., \& Rianto, E. (2001). Economic crisis, small farmer well-being, and forest cover change in Indonesia. World Development, 29(5), 767-782. http://dx.doi.org/10.1016/S0305-750X(01)00009-2

Vrolijk, F. (2013). The local impacts of land grabbing for biofuel feedstock plantations in Ghana. Van Hall Larenstein University of Applied Sciences, Tropenbos International, August 2013 Velp, Netherland. Retrieved June 21, 2014, from http://edepot.wur.nl/279722 


\section{Copyrights}

Copyright for this article is retained by the author(s), with first publication rights granted to the journal.

This is an open-access article distributed under the terms and conditions of the Creative Commons Attribution license (http://creativecommons.org/licenses/by/3.0/). 